\title{
PLUTONIUM IN HAYSTACKS
}

There is a delicate irony in the arrival of the InspectorGeneral of the International Atomic Energy Authority at the Bradwell nuclear power station only a few days before the fourth test of a nuclear weapon on the mainland of China. Mr. A. D. McKnight found nothing wrong at Bradwell, of course. His visits to other nuclear reactors have been equally unspectacular, and nobody knows what he would do if one of his inspectors did actually discover that the operator of some nuclear installation was salting away fissile material. The regulations of the IAEA say that offenders can be denied the privileges of membership, but that threat is not likely to worry potential bomb makers. The safeguards programme of the IAEA is usually voluntary. Only two power reactors-one in the United States and one in the United Kingdom-have been opened to inspection. Most of the research reactors on the agency's books are there either because nations such as the United States have tried to help the agency by asking it to assume responsibility for inspections that would otherwise be carried out under the terms of bilateral agreements, or because nations accepting technical assistance with reactors have found it easier to accept inspection by the agency than by the original donor. Yet one of the motives for the creation of the agency eight years ago was to make possible an international system of safeguard and control extending even to the international ownership of fissile material. Has it become a joke ?

It is, of course, a disappointment that the international agency has so far fallen short of its main objectives on safeguards and inspection, but its position could easily have been far worse. Five years ago, the agency was extremely lucky to win agreement for a tentative and modest programme of safeguards for research reactors. Much to the surprise of the then nuclear powers, nations without nuclear weapons of their own were unwilling to give the international agency a blank cheque to inspect reactors built in foreign parts. The underlying trouble, which should have been predicted, was that the non-nuclear powers could not easily stomach a system of international inspection intended to preserve what seemed to be the imbalance of power and influence between the nuclear powers and themselves. There were also arguments which turned on the concept of national sovereignty, and which drove a wedge among the nuclear powers in their mutual and implicitly recognized concern to prevent the spread of nuclear weapons. Some nations protested that if they paid good money for a reactor, they were in principle the masters of what uses should be made of it. In the circumstances it is something of a triumph that safeguards were eventually applied on a voluntary basis to research reactors, and that their scope has now been extended to deal with larger installations. What Mr. McKnight and his men are doing is to show that inspection can be carried out without making the operation of a reactor uneconomic. The reactors in the trials will be less stringent tests of the efficacy of the safeguards because the operators wish to demonstrate that safeguards work and have therefore an interest not to cheat. It remains to be seen whether the present trials will be sufficiently definite to persuade the nations represented at Vienna - nuclear and otherwise-that the present safeguards are a sufficient basis for a lasting agreement.

The safeguards now being worked out will almost certainly be a great convenience to the nations which supply others with reactors, and that will be a public service. But will the safeguards ever become the basis of a comprehensive system for controlling the spread of nuclear weapons? Will member nations ever agree that all their nuclear installations should come under the control of the international agency? And will they accept effective penalties for breaking the agreements? These questions are so full of difficulty that they have hardly been raised, at Vienna or elsewhere, in the past few years. One of the more obvious problems is that the non-nuclear powers are unwilling to accept a system of controls which would prevent them from making nuclear weapons but which would allow the existing nuclear powers to enjoy such benefits as there may be in their possession. This turned out to be the chief stumbling block, five years ago, in the negotiation of safeguards for research reactors. It has also impeded progress, in the United Nations disarmament committee, with the negotiation of what is called a non-proliferation treaty. Obviously there will have to be some concession by the existing nuclear powers if safeguards are ever to serve the purpose for which they were originally intended. A verified cessation of production of fissile material for military purposes is probably the smallest concession that would be acceptable to the nations at Vienna not now possessed of nuclear weapons. But the nuclear powers are not in the mood for such a step, and all the member nations at Vienna are well aware of the ease with which nations would be able to contract out of a voluntary agreement. Indeed, the most recent nuclear power is not a member at all. In the circumstances, it is not, perhaps, surprising that people have become despondent about the usefulness of the Vienna safeguards, either now or in the future, but that is needlessly pessimistic. If there is ever to be an effective control on the spread of nuclear weapons, safeguards will be essential; the fact that workable proccdures are now being designed should be a spur to tackle the more difficult problems that lie ahead, and not so very far ahead. It will not be long before power reactors are widely scattered through the world. 